International Journal of Applied Linguistics \& English Literature

ISSN 2200-3592 (Print), ISSN 2200-3452 (Online)

Vol. 1 No. 5; September 2012 [Special Issue on General Linguistics]

\title{
Globalization And English Language Education In Nigeria
}

\author{
Dr. (Mrs) Hanna Onyi Yusuf \\ Department of Educational Foundation and Curriculum \\ Faculty of Education Ahmadu Bello University, Zaria, Nigeria \\ Tel: +2348033207255_ E-mail: Hannayusuf@yahoo.com
}

Received: 30-07- 2012

Accepted: 23-08- 2012

Published: 03-09- 2012

doi:10.7575/ijalel.v.1n.5p.202

URL: http://dx.doi.org/10.7575/ijalel.v.1n.5p.202

\begin{abstract}
Education and ethnicity, culture and religion, and indeed all of man's endeavour cannot be discussed without taking language into account. This paper therefore discusses language complexity and ethnic plurality which is largely brought about as a result of globalization. Globalization processes such as immigration and internationalisation lead to contact situations in which different people with their different and or distinct languages and cultures meet. These contacts have consequences at a content level i.e for the languages and cultures involved at an individual level i.e for the users of these languages and cultures; and at an institutional level, i.e for the societal structures in which these languages and cultures are situated. The paper further reveals that while there is now greater recognition of the importance of language both for economic and educational development, as well as human rights, the forces of globalization are leading towards uniformity in the language use, in culture and even in education.
\end{abstract}

Keywords: Globalization, Language Education, Nigeria, Ethnic plurality

\section{Introduction}

The concept of globalization is global and dominant in the world today. But, it was not handed down from heaven, it was not decreed by the holy of holies, it did not emerge spontaneously. It was created by the dominant social forces in the world today to serve their specific interest. Simultaneously these social forces gave themselves a new ideological name "The international community" - to go with the idea of globalization (Madunagu 1999).

Globalization has largely been driven by the interests and needs of the developed world (Grieco and Holmes, 1999). It has turned the world into a big village. This inturn has led to intense electronic cooperation or commercial war to get the attention and nod of the global world. This war for survival can only get more intense in the new millennium.

It is needless to distractedly search for any premise other than the foregoing to commence the analytical examination of the holocaust effects of globalization particularly as it affects the continent of Africa and Nigeria in specific. It should be stated, however that the extent of these effects as well as the coping ability/capacity of its victims are explainable within the context of human history, which on its own has not been static and which had continuously evolved with the society itself over the years. In the course of this evolution, various developments and changes had taken place. These changes or developments had in most cases affected the systematic existence of humankind regardless of the geographical location within the universe.

One of such changes or developments that is currently affecting the human society today through its imposition of constraints on the policy-making autonomy or independence of member states vis-à-vis their capacities for the authoritative allocation of scarce and critical societal values or resources among other functions, is globalization. As a result of its combination of "destructive leviathan" and improved material well-being of humankind, it has continued, however, to attract increased scholarly and analytical attention across the globe. It is thus not fortuitous that globalization has been at the epicentre of most development and intellectual discourses.

This is unconnected with the fact that world developments have been increasingly characterised not by their growth dynamics but by their links to the process of globalization. Hence, the overwhelming character of globalization has made it compelling for some scholars to use various aspects of global economy as units of analysis.

\section{The concept of Language}

When one consider the social forms and physical artifacts of human societies, one is struck by the diversity of cultures in different times and places. Some humans walk on foot, others ride camels and horses, while others fly 
International Journal of Applied Linguistics \& English Literature

ISSN 2200-3592 (Print), ISSN 2200-3452 (Online)

Vol. 1 No. 5; September 2012 [Special Issue on General Linguistics]

on the plane and or ride rockets to the moon. But in all the societies where these people could be and are found, there is a language. This essential connection between having language and being human is one reason why those interested in the nature of human minds have always been particularly intrigued with language.

To philosophers such as Descartes among others, Language was that function which most clearly distinguish us from beasts and was the sole sign and only certain mark of thought hidden and wrapped up in the body. He held that humans were utterly different from other animals because all humans have language while no other animals have anything of the sort.

Comrie, 1987 added that human languages are at bottom much more alike than they seem at first glance. For example, all languages convey thought by the same means. They all use words and sentences to organise ideas. In contrast, animal communication often have nothing like words. For instance, a cat can purr happily or hiss angrily but they never have complicated sentences as man does.

Another similarity is in the ideas human language can express. For example, when an Igbo man makes a speech in an occasion (in Igbo), numerous translators immediately whisper its equivalent in English, Hausa, Yoruba, Tiv etc to the listening dignitaries from other ethnic groups. The fact that Igbo can readily be translated suggest that by and large, the same things can be said in Yoruba and or Hausa, French or Arabic and yet be translated accordingly.

\section{Properties of human language}

\subsection{Language is creative}

At first glance, language might seem to be merely a complicated habit, a set of acts of ear and mouth that have been learned by memorization and practice. According to this view, the explanation of talking is simple: each memorized speech act is simply performed wherever the appropriate circumstances arise. For instance, a mother may say "That is a bird", when she sees one. Thus, her child, anytime he/she sees anything of the sort say "That is a bird", e.t.c.

In sum, people effortlessly create and interpret new sentences on the spot. To express all these thoughts, humans combine a limited though large number of words into sentences. Thus language is a system that allows us to reach limitless end from limited means. People can do this because human language system allows them to combine the old words in novel ways (Bloomfield, 1933; Chomsky, 1959).

\subsection{Language is structured}

While language use is creative in the sense that human can invent new sentences all the time, it is also restricted. There are unlimited number of strings of English Words that humans would never utter. For instance, people do not say "is bird a that", or "bird that is a". Speakers construct their utterances in accord with certain abstract principles of language structure. These structural principles underline the way in which people combine words to makeup new sentences without special thought or formal training in school.

\subsection{Language is meaningful}

Each word in a language expresses a meaningful idea (or concept) about something (e.g television or puppy); action (sit or run); abstraction (justice or fun), quality (blue or altruistic) and so on. The purpose of language is to express all these meanings so people have no choice but to learn a conventional word for each.

\subsection{Language is referential}

Language users know more than how to put words together into meaningful and grammatical sentences. They also know which word refer to which things, scenes, and events in the world. If a child says "that is a kitten" (a sentence whose grammar is impeccable and whose meaning is transparent) but did so while pointing to a box, people would not think they have learned English very effectively. This is the problem of reference: how to use language to describe the world of real things and events - saying 'kitten' to make reference to a kitten, and 'box' to refer to a 'box' respectively.

\subsection{Language is interpersonal}

Many aspects of human language are within the individual and are thus the property of each single human mind. But language is a process that goes beyond the individual, for it is a social activity in which the thoughts of one mind are conveyed to another. To accomplish this social ends, each speaker must know not only the sounds, words and sentences of his languages but also certain principles of conversation. These principles govern the way in which language is used appropriately under varying circumstances. Suppose, for example, that one sees a lion in the parlour and wants to tell a companion about this. He/she mustn't speak English to his companion. They are non-verbal cues he will employ in communicating to his colleague who may understand.

\section{The concept of Globalization}

Globalization refers to the process of the intensification of economic, political, social and cultural relations across international boundaries. It is principally aimed at the transcendental homogenization of political and social-economic theory across the globe. It is equally aimed at making the global initiative present worldwide. It 
International Journal of Applied Linguistics \& English Literature

ISSN 2200-3592 (Print), ISSN 2200-3452 (Online)

Vol. 1 No. 5; September 2012 [Special Issue on General Linguistics]

deals with the increasing breakdown of trade barriers and the integration of world market (Fafowora, 1998:5). In the words of Ohuabunwa, (1999:20),

"globalization can be seen as an evolution which is systematically restructuring interactive phases among nations by breaking down barriers in the areas of culture, commerce, communication and several other fields of endeavour".

The reality in Nigeria today as it is for most African nations is that globalization has made it immensely difficult for governments to provide social insurance and a unified language or as technically called , "Lingua Franca". Trends like this have been largely dictated by the assumption of powers that accompany globalization (i.e inequality in the status of the members of the "villagized world" and their inability to resist imposed policy options). Infact, this asymmetry which is undergirded by a system of production where finance/capital rules has been clearly amplified by Madunagu (1999) when he claimed that:

"The result of globalization in Africa is basically a competition between the palatial centres (developed world) and the slum, (Africa) of the village where a preponderant majority of the people daily sink deeper into poverty and misery.

Consequently, its (globalization) ideology remains a continuous licence for culture imperialism, and, the institutionalisation of both political and economic domination and exploitation of the weaker partners through their internal agents (Tandom: 98). This imperialistic cultural dimension of globalization, particular in the area of "internet connectivity" which has often been used as a bait for luring Africa and other development polities into the villagized world, has recently been put into perspective thus:

The world is gradually moving in a unidirectional manner and the tendency towards uniformity has never been so appealing as it is now. Consequently, there is a serious concern that the internet pool that is now low may lose their identity (Otokhine, 2000:2).

Generally speaking therefore, globalization has become more of a threat to the poor rather than an opportunity of global opportunity for global action to eradicate poverty. Given the foregoing, Obadina (ibid) argued that globalization is anchored in "the ethos of "winner takes all" and a " beggar-their- neighbour" philosophy irrespective of its seeming moral terms of freedom, and this in itself has increased the debt burden of most countries in Africa.

\subsection{Globalization and the transfer of information}

Globalization brings new innovation, technology, language, just name it. On the basis of argument, globalization brings (for instance) new technology and opposition to globalization is not tantamount to becoming technologically isolated from the rest of the world. For instance, the case of GSM today. Prior to its lunch at the start of the millennium, getting connected to the rest of the world was seen as luxury that only the wealthy can afford, even though it still poses some problems at the time. Line congestion, roaming, among others are notable disadvantages. But today, any man can call his/her friend or family member in any part of the world without little or no hitch. This is also the case with language.

Advocates of globalization have often made the claim that globalization, through its elements brought the language envogue in Nigeria today (English). It is worth mentioning here that before the advent of English Language, Nigeria and indeed Anglophone Africa has a language of communication. As said above, English language has become pre-dominant because of so many reasons.

First, the whites, (our colonial masters) speak it, and to 'belong', one has to speak it. Secondly, our sons and daughters were educated through the medium of communication-English, some of whom were taken abroad for further studies to take over the realm of affairs from them later when they feel they should relinquish power to the indigenes. Thirdly, most literature came in English. Most indigenous languages have little or no form of written document to serve as a guide to the up-coming generation. The languages (native) have no found orthography. Therefore, as soon as English language came forth, with its attendant availability of written guides, the masses learnt it, more so because it is the only way to interact with the native world, which at the time was controlled by the whites - The English. This is why David Graddol argued that:

"we are entering a phase of Global English which will shape future identities, economies and culture. The way this language is managed could determine the future of several generations" (English Next, 2006, P. 109).

As is the case among many ESL nations, English is operational in the political, social and institutional contexts which impacts on everything done. When students enter tertiary institutions, they already have experiences of learning English. They also have expectations about what language learning involves and what constitutes success. These are based in part on their earlier language learning and assessment experiences. Tertiary level instructors are to some extent often constrained by these expectations. 
International Journal of Applied Linguistics \& English Literature

ISSN 2200-3592 (Print), ISSN 2200-3452 (Online)

Vol. 1 No. 5; September 2012 [Special Issue on General Linguistics]

In common with many countries throughout Africa, Nigeria regards English language as critical to its future. All these could be said to be as a result of globalization.

\section{The English Language as a global force}

The English language is the second most widely spoken tongue in the world today. Of the 6912 living languages listed in the Ethnologue language database, only Mandarin is spoken by more people. But it is the English language however that seems to be having a bigger impact on the world as a whole and has become the global de-fact standard used in business, cultural and political exchange; education, religion etc.

The integration or coming together of the world's cultures and economies is commonly known as globalization, and a shift in language usage and language demarcation is closely bound to these global changes. These international shift and trends affect the languages that we all speak, which in turn have a marked effect on the functions and organisation of our brains and the way that we think. Due to the rise of globalization, it seems that the English language more than any other language is having a most pronounced and lasting impact on the collective networks of the world mind

The English language has over 500 million people that speak it, with 340 million of these using it as their primary or first languages. Perhaps one reason why the English language has become such an international force is because of its ability to adopt and mutate in the face of change, an open ended philosophy that has certainly served it well. English as a means of communication is good at incorporating the other languages into its own language as can be seen with the many words and phrases originally from other languages that most people would now consider authentically English. The strength of English language is that it accepts these variations and integrates them into itself effectively.

There is a huge cultural uptake of English, with dozens of variations on the language coming into existence as people have shaped it with their own cultural conditioning. These differing versions of the language are still understandable as English however, and have helped it to evolve and grow at a rapid rate.

English has become a sort of common denominator in international affairs, as it has a fairly open ended linguistic structure and is able to be understood in a wide variety of circumstances. The birth of the internet in an English speaking country has also had a huge impact on this global evolution of the language, with almost $80 \%$ of the world's digital information now stored in English. The internet is basically English oriented, as most of the large search engines are based in the USA and the major computer languages themselves are a kind of sub set of the English language. This alone has been a huge effect on globalization and has meant that English speaking countries are at a definite advantage when it comes to communication with the world as a whole.

5.1 Language and globalization

By definition, language is a body of words and the systems for their use common to people who are of the same community, nation, geographical area, or the same cultural tradition (Collins Dictionary, 2009).

The online Etymology dictionary (2010) defines it as communication by voice in the distinctively human manner, using arbitrary sounds in conventional ways with conventional meanings. It is also defined as the system of linguistic signs or symbols considered in the abstract (the language monitor, 2011). The American dictionary of science (2010) on its part defines it as a system of objects or symbols, such as sounds or character sequences, that can be combined in various ways into a set of rules especially to communicate thoughts, feelings or instructions.

On the other hand, globalization is the worldwide movement toward economic, financial, trade, and communications integration. It implies the opening of local and nationalistic perspectives to a broader outlook of an interconnected and independent world with free transfer of capital, goods and services across national frontiers (UNESCO, 2010).

It is also seen as the movement from standard domestic business operations to a more international operation. Various aspects such as increased use and abilities of technology have made globalization both possible and easier. Globalization processes and their outcome have led to an increasing knowledge in scaling process, worldwide movements of people, goods and services, ideas and a growing influence of telecommunication and new media in the communicative and cultural landscape. On another hand, these processes tend to pose a descriptive challenge. These processes, movements and influences are not yet sufficiently understood and have to be analysed in detail using a variety of methods. Three main methods/domains are hereby classified to drive home the links between language and globalization.

\subsection{Language and culture contact}

With respect to language, there is special attention for processes of language mixing, code switching, language change and the emergence of new varieties, registers or hybrid codes. A thorough study of these phenomena especially as a consequence of globalization show more speed and scope at the same time. 
International Journal of Applied Linguistics \& English Literature

ISSN 2200-3592 (Print), ISSN 2200-3452 (Online)

Vol. 1 No. 5; September 2012 [Special Issue on General Linguistics]

\subsection{Language and literacy acquisition}

The acquisition of language and literacy focuses on formal (educational) as well as informal contexts (via popular culture, new media, peer groups etc). especially the way in which the acquisition of language and literacy is influenced by globalization processes. Increased and diversified migration processes lead to new forms or language and literacy acquisition that are often considered problematic in formal contexts. The influence of new technologies leads to a growing role for mediation and multimodality in using language and literacy.

5.4 Language, culture, ideology and policy

In the context of globalization new questions with respect to the relationship between language, culture and identity came into existence, and now these questions are also discursively shaped in media, policy and popular culture.

\section{Globalization of language}

An example of globalization one finds in daily life is the enormous stream of English words (or words that only seem to be English) into our language. It seems as if the sprung of these words has increased during the last decade in a terrifying way. There is almost no company, whether its operation is international or not, that uses indigenous slogans anymore. Most people speak English and also our daily lives is full of English influences. This enforces the assumption that living languages complement each other, and as it does not become too dominant, a language can only win through such a completion.

It may be funny but it gives concern if indigenous words or pidgin everybody usually understands are exchanged for English words without any reason. The case is however more complex and delicate for a multi-lingual nation like Nigeria. For example, the word "chop" in pidgin as every Nigerian understands it means "eat" (come and chop) meaning (come and eat). Imagine saying this to an American or a Scotish. "Chop" in the real English language context means to "cut into shreds". So, telling an Irish or Australian to "come and chop" while he may be confronted with a bowl of food and not vegetable, fruits or the likes would rob him/her of an understanding of any sort. In Germany, "body bag" means a modern bag that is usually carried with one strap over the shoulder, but in English it means a bag to transport corpses, usually in cases of accidents, by paramedics, police etc.

Globalization is sign of a high openness against other cultures, and of the distances between nationals to get narrower, and it also shows the global impact of the English language that offers people an opportunity to communicate all over the world, an opportunity we have to be dreadful for. But on the other hand it is also one of the biggest dangers for our language. It shows that from now on, every other language will have to settle for second behind the English.

\section{Conclusion}

In today's globalised world, governments and minorities are faced with conflicting pressures on one hand, for the development and use of language (and education) in a global/international language; on the other hand for the use and development of mother tongue, local or indigenous languages in education.

Language complexity and ethnic plurality were largely brought about as a result of the creation of nation-states which were spread around the world as a result of European colonialism. European languages and formal education system were used as a means of political and economic control. The legacy that was left by the colonial powers has complicated ethnic relations and has frequently led to conflict. While there is now greater recognition of the importance of language both for economic and educational development as well as human rights, the forces of globalization are leading towards uniformity in the languages used, in culture and even in education. They are working against the development of language rights for smaller groups.

We are witnessing a sharp decline in the number of languages spoken. Only those languages which are numerically, economically and politically strong are likely to survive. As a result many linguistic and ethnic groups are in danger of being further marginalised.

\section{References}

Bloomfield, B. (1933). Language. New York: Lawrence Earlbaum.

Chomsky, N. (1959). The property of language Encarta.com/linguistic/noamchomsky.html

Collins Dictionary (2009). London: Pearson

English Next (2006). Journal of English Language as second language (ESL) P. 109 www.tilburguniversity.edu/babylon Fafowora, O.O. (1998). Management Imperatives of Globalization Management in Nigeria; Journal of Nigerian Institute of Management. Vol 34, Nos 2-4, April-December.

Grieco, M., Holmes, L. (1999). Telecommunication options for community Business. An opportunity for economic growth in Africa. Africa Notes (October) pp 1- 3.

Madunagu, E. (1999). “Globalization and its victims". The Guardian (July $26^{\text {th }}$ ) P. 53. 
International Journal of Applied Linguistics \& English Literature

ISSN 2200-3592 (Print), ISSN 2200-3452 (Online)

Vol. 1 No. 5; September 2012 [Special Issue on General Linguistics]

Obadina, T. (1998). “Globalization, Human Rights and Development”. Africa Today (Oct) pp 32-33.

Ohuabunwa Mazi, S.I. (1999). The challenges of Globalization to the Nigerian Industrial Sector. Nigerian Tribune (Dec.14) pp 20- 21.

Otokhine, E. (2000). Internet strengthens culture imperialism. The commet (August 23) p. 21.

Tendon, Y. (1998:a). Globalization and Africa's options. AAPS Newsletter: Harare. AAPS Vol. 3, No. 2, May/August.

The Language Monitor (2011). online Encarta.msn/language encyclopedia 761570647.html

The online Etymology Dictionary (2010). London: Routledge

Unesco, (2010). Language of Globalization. Biennial Newsletter, March. New York: UN press. 